\title{
黄土塬面保护区潜在蒸发量时空变化 及其与气象、环流因子关系分析
}

\author{
孙从建 ${ }^{1,2}$, 郑振婧 ${ }^{1}$, 李新功 ${ }^{1}$, 孙九林 ${ }^{1,3}$ \\ (1. 山西师范大学地理科学学院, 临汾 $041000 ; 2$. 中国科学院荒漠与绿洲生态国家重点实验室, \\ 乌鲁木齐 $830011 ; 3$. 中国科学院地理科学与资源研究所, 北京 100101)
}

\begin{abstract}
摘要：黄土塬面是黄土高原地区主要的农业分布区和人口聚居地, 地位十分重要。黄土塬面 潜在蒸发量 $\left(E T_{0}\right)$ 的研究对于区域水循环研究、水土流失防治及农业的可持续发展具有重要意 义。基于黄土塬面保护区 1960-2017年的气象数据, 利用 Penman-Monteith 模型、小波分析、 Mann-Kendall 非参数检验等方法研究了黄土塬面保护区 $E T_{0}$ 的变化规律及其与气象、环流因子 间的关系。结果表明: (1) 黄土塬面保护区多年平均 $E T_{0}$ 为 $1173.4 \mathrm{~mm}$, 总体呈现增长趋势, 增长 率为 $21.1 \mathrm{~mm} / 10 \mathrm{a}$; 其生长季平均 $E T_{0}$ 值及增长率均高于非生长季平均 $E T_{0}$ 。 (2) 该区多年平均 $E T_{0}$ 空间分布特征表现为东部高西部低, 西部甘肃塬区多年平均 $E T_{0}$ 远低于东部山西塬区。(3) 过去 58 年来, 区域年均、生长季、非生长季 $E T_{0}$ 均呈现出增长趋势, 但空间差异明显; 研究区年均 $E T_{0}$ 存在着 10 年、 30 年和 50 年的震荡周期, 其中以 30 年周期为主周期。(4)气温是控制区域 $E T_{0}$ 变化的最重要的气象因子, 但气温对 $E T_{0}$ 的影响具有明显的空间差异, 在整个研究区内最低气 温影响最显著; 而甘肃塬区和陕西塬区的 $E T_{0}$ 变化主要受平均气温变化的控制, 在山西塬区最 高气温的变化是区域 $E T_{0}$ 变化的主要控制因子。(5)遥相关分析结果显示太平洋/北美指数 (PNA) 与北大西洋年代尺度振荡 $(\mathrm{AMO})$ 对该区域 $E T_{0}$ 变化有一定影响, 西太平洋海温指数 (WPI) 的变化影响区域非生长季 $E T_{0}$ 变化。
\end{abstract}

关键词：潜在蒸发量;Penman-Monteith模型;时空分布;影响因子;黄土塬面保护区

潜在蒸发量 $\left(\mathrm{ET}_{0}\right)$, 是指在水分充足的情况下可蒸散到空气中的总水量, 其对区域 水分分配具有显著的影响 ${ }^{[1,2]}$ 。作为全球水循环的重要环节, $E T_{0}$ 的变化直接影响区域干湿 状况、植物的生长及区域水资源供需平衡 ${ }^{[3]}$ 。准确地估算区域 $E T_{0}$ 并探索其时空分布规律 对于区域生态环境的保护、水土流失的防范及区域水资源的优化配置具有重要意义 ${ }^{[4]}$ 。

已有学者研究了部分区域 $E T_{0}$ 的变化特征。其中, 伊朗地区 ${ }^{[5]} E T_{0}$ 研究结果表明, 温 度、相对湿度及风速对区域 $E T_{0}$ 变化影响较大; 在澳大利亚, 气象因子对不同气候区的 $E T_{0}$ 的影响存在显著差异 ${ }^{[6]}$ 。在中国, 大量的研究表明, 温度、湿度及风速等气象因子对 我国北方地区 $E T_{0}$ 变化有着直接影响 ${ }^{[7-11]}$ 。此外, 大气环流因子的改变也会引起区域 $E T_{0}$ 的 变化, 其中太平洋/北美指数 (PNA) 及西太平洋海温指数（WPI）等大气环流因子的变 化被证明对我国北方地区降水、温度及 $E T_{0}$ 的变化具有显著影响 ${ }^{[12-14]}$, 长江源区的研究表 明该区域 $E T_{0}$ 变化与大尺度环流因子间存在显著的遥相关关系 ${ }^{[15]}$ 。在黄土高原地区，以往

\footnotetext{
收稿日期：2019-01-18；修订日期：2019-07-05

基金项目：国家自然科学基金项目（41601317）; 荒漠与绿洲生态国家重点实验室开放基金项目（G2018-02-06）

作者简介：孙从建（1986- ), 男, 河北沧州人，博士，副教授，主要从事气候变化与水循环研究。

E-mail: suncongjian@sina.com
}

通讯作者: 李新功 (1967- ), 男, 北京人, 博士, 研究员, 主要从事水循环研究。E-mail: lixi@ku.edu 
研究发现该区多年平均 $E T_{0}$ 变化在 780 1470 $\mathrm{mm}$ 之间, 并在空间上呈现出西北高东南低 的趋势 ${ }^{[7]}$, 区域 $E T_{0}$ 变化与气象因子之间具有密切的关联性 ${ }^{[8]}$ 。此外, 黄土高原内部的 $E T_{0}$ 变化规律表现出显著的空间差异性，如高原北部 ${ }^{[0]}$ 及典型丘陵沟壑区 ${ }^{[10]}$ 的多年 $E T_{0}$ 变化呈 现下降趋势; 而东部山西地区的多年 $E T_{0}$ 变化却呈增长趋势 ${ }^{[1]}$ 。上述研究结果对认识区域 蒸散发过程具有重要意义。然而现有的潜在蒸散发研究涉及到黄土高原塬面区域的甚 少, 黄土塬面区的蒸散发时空变化特征仍不甚明确。在全球气候变化背景下, 气象因 子、大气环流因子等变化是否带来该区 $E T_{0}$ 的时空分布变化, 已成为当前相关研究者密切 关注并亟待解决的问题。

近年来，水土流失导致黄土塬面萎缩、耕地锐减，粮食减产，黄土塬面地区生态安 全问题日益严重 ${ }^{[16]}$, 已阻碍了黄土高原地区的经济可持续发展。为此, 水利部出台了专 门的黄土高原塬面保护规划, 将陕西、山西及甘肃三省主要塬区设为黄土塬面水土流失 防护及治理的重点保护区。该区位于我国东部季风区与西北干早区的交汇处, 地理位置 十分重要，对气候变化极其敏感。开展黄土塬面保护区的 $E T_{0}$ 时空变化规律及其影响因素 研究, 对于认识区域水循环过程、提升塬面地区应对气候变化的能力具有重要意义。鉴 于此, 本文利用研究区多年的气测数据资料开展了该区域 $E T_{0}$ 变化规律及影响因素的研 究, 以期弥补黄土高原塬面潜在蒸发研究的不足, 提升区域水土流失防治的能力。

\section{1 研究方法与数据来源}

\section{1 研究区概况}

黄土塬面作为黄土高原的典型台地，地势较平，耕地集中，农、林、牧等资源较丰 富, 人口分布集中, 是黄土高原地区粮食生产的主体功能区 ${ }^{[17]}$ 。黄土塬面保护区主要包 括山西西南部的太德塬、陕西北部的洛川塬以及甘肃东部的董志塬等主要塬区, 总面积 约 5.58 万 $\mathrm{km}^{2}{ }^{[18]}$, 该区域位于黄土高原腹地, 地势平坦且开阔，但塬沟相间、沟壑纵横 ${ }^{[19]}$ （图 1)。该区域兼具温带大陆性气候与温带季风气候的特征, 多年平均年降水量在 450 709 mm之间, 降水多集中于夏季, 且分配极不均衡, 该区域多年年平均气温为

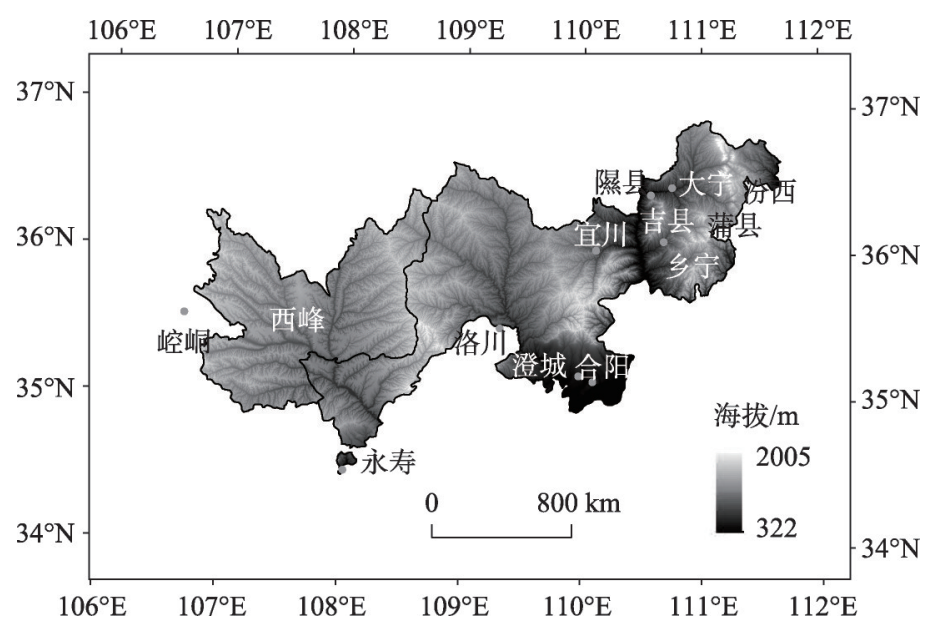

图 1 黄土塬面保护区地理位置及气象站点分布

Fig. 1 Distribution of meteorological stations in the tableland protected region of the Loess Plateau 
$8 \sim 15.6^{\circ} \mathrm{C}$, 年日照时数在 2099 2900 h 之间 ${ }^{[18]}$ 。黑垆土、黄绵土为研究区主要的土壤类 型，耐旱草本及松树、柏树、榆树等温带针叶落叶阔叶乔木为当地主要的植被。

\section{2 数据来源}

本文选取黄土塬面保护区内及其邻近的大宁、西峰、洛川等 13 个气象站点, 研究数 据主要包括各站点 $1960-2017$ 年间的风速 $(\mathrm{m} / \mathrm{s})$, 日平均气温 $\left({ }^{\circ} \mathrm{C}\right)$, 日最低气温 $\left({ }^{\circ} \mathrm{C}\right)$, 日最高气温 $\left({ }^{\circ} \mathrm{C}\right)$, 日照时数 $(\mathrm{h})$, 相对湿度 $(\%)$ 及平均水气压 $(\mathrm{kPa})$, 经纬度和高程 数据。气象数据下载自中国气象局国家气象信息中心（http://data.cma.cn/site/index.ht$\mathrm{ml}$ ），而大尺度环流因子数据来源于 NOAA 网站（http://www.esrl.noaa.gov/psd/data/climateindices）。为了评估农事活动与 $E T_{0}$ 的关系，本研究将年内分为生长季（农事活动集 中的 4-10月) 及非生长季 (11月至次年3月)。为了进一步验证计算结果的正确性, 本研 究选取乡宁、蒲县、吉县和汾西 4 个站点的蒸发血蒸发量数据与 $E T_{0}$ 计算值进行了数据一 致性检验。

\section{3 研究方法}

\subsubsection{Penman-Monteith模型}

本文的 $E T_{0}$ 计算选用 FAO 修订后 Penman-Monteith 模型 ${ }^{[20]}$ 。其模型如下:

$$
E T_{0}=\frac{0.408 \Delta\left(R_{n}-G\right)+\gamma \frac{900}{T+273} u_{2}\left(e_{s}-e_{a}\right)}{\Delta+\gamma\left(1+0.34 u_{2}\right)}
$$

式中： $E T_{0}$ 表示潜在蒸发量 $\left(\mathrm{mm} \cdot \mathrm{d}^{-1}\right) ; \Delta$ 代表饱和水汽压曲线斜率 $\left(\mathrm{KPa} \cdot{ }^{\circ} \mathrm{C}^{-1}\right) ; R_{n}$ 是太阳净辐射 $\left(\mathrm{MJ} \cdot \mathrm{m}^{-2} \cdot \mathrm{d}^{-1}\right) ; G$ 为土壤热通量 $\left(\mathrm{MJ} \cdot \mathrm{m}^{-2} \cdot \mathrm{d}^{-1}\right) ; \gamma$ 为干湿常数 $\left(\mathrm{KPa} \cdot{ }^{\circ} \mathrm{C}^{-1}\right)$; $u_{2}$ 表示离地面 $2 \mathrm{~m}$ 高处的风速 $\left(\mathrm{m} \cdot \mathrm{s}^{-1}\right) ; T$ 为平均气温 $\left({ }^{\circ} \mathrm{C}\right) ; e_{s}$ 是饱和水 汽压平均值 $(\mathrm{kPa}) ; e_{a}$ 代表实际水汽压 $(\mathrm{kPa}) ;\left(e_{s}-e_{a}\right)$ 为饱和水汽压差值 $(\mathrm{kPa})$ 。

\subsection{2 趋势及周期分析方法}

采用趋势分析及周期分析法来研究 $E T_{0}$ 的时间变化，空间分布主要采用 ArcGIS 地统 计模块的克里金插值法 ${ }^{[21]}$ ，其中空间趋势变化选取在水文和气象数据研究中运用较多的 Mann-Kendall检验 ${ }^{[22-23]}$ 。Morlet 小波被用于分析本研究的周期变化规律 ${ }^{[24]}$ 。

\subsection{3 相关分析与贡献率计算}

运用相关分析对 $E T_{0}$ 的主要影响因素进行辨别，并将各气象因子对区域 $E T_{0}$ 变化的相 对贡献率进行计算。各气象因子对 $E T_{0}$ 的相对贡献率即其对应系数的绝对值除以所有回归 系数绝对值的和 ${ }^{[25]}$, 其公式如下:

$$
\begin{gathered}
Y=a_{1} X_{1}+a_{2} X_{2}+a_{3} X_{3}+\cdots+a_{n} X_{n} \\
g_{1}=\frac{\left|a_{1}\right|}{\left|a_{1}\right|+\left|a_{2}\right|+\left|a_{3}\right|+\cdots+\left|a_{n}\right|}
\end{gathered}
$$

式中: $Y$ 表示 $E T_{0}$ 的标准化值; $X_{1}, X_{2}, \cdots, X_{n}$ 分别为气象因子的标准化值; $a_{1}, a_{2}, \cdots, a_{n}$ 为序列标准化后的回归系数; $g_{1}$ 为 $X_{n}$ 变化对 $Y$ 变化的相对贡献率。

\section{2 结果分析}

\section{1 塬面保护区 $E T_{0}$ 的时间变化特征}

研究区 1960-2017 年间的平均 $E T_{0}$ 值为 $1173.4 \mathrm{~mm}$ ，年际倾向斜率为 $21.1 \mathrm{~mm} / 10 \mathrm{a}$, 总体呈增长趋势（图2）。在 1964 年观测到了区域 $E T_{0}$ 最小值 $(1031.4 \mathrm{~mm}$ ), 而在 1997 年 
观测到了该区域 $E T_{0}$ 的最大值 $(1293.3 \mathrm{~mm})$ 。在 $1960-1994$ 年间，年均 $E T_{0}$ 整体保持低位 震荡，年均 $E T_{0}$ 除 1986 年、1987 年接近 $1200 \mathrm{~mm}$ 外，其余均在 $1200 \mathrm{~mm}$ 以下。而在 $1995-2017$ 年间，年均 $E T_{0}$ 值除 1996年和 2003 年外，其余年份均整体较大，大部分年份 $E T_{0}$ 大于 $1200 \mathrm{~mm}$ 。
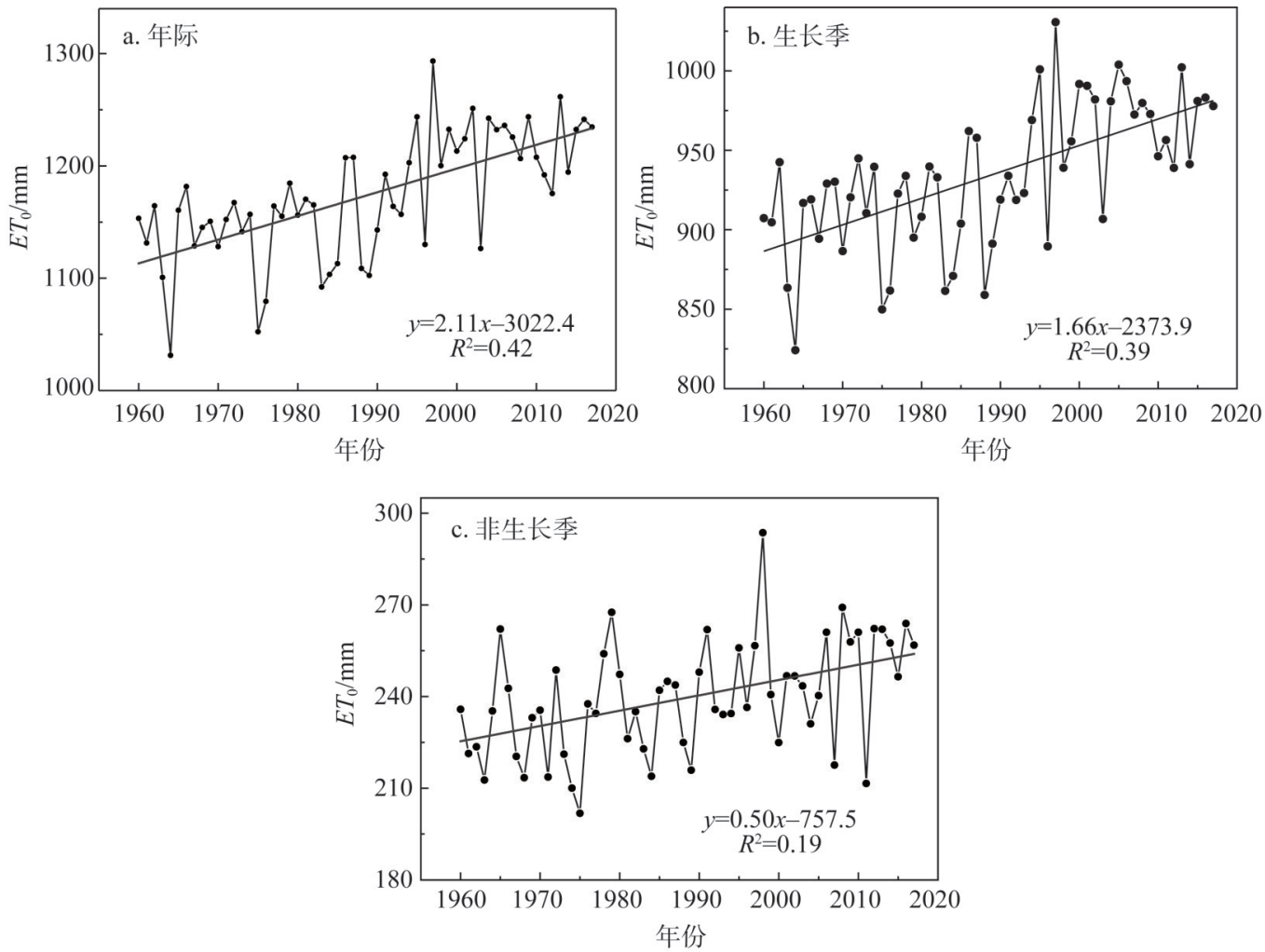

图 2 1960-2017年间黄土塬面保护区 $E T_{0}$ 变化趋势

Fig. 2 Variation of potential evapotranspiration in the tableland protected region of the Loess Plateau during 1960-2017

作物的生长已被证明对于区域 $E T_{0}$ 的变化具有显著的影响 ${ }^{[26]}$ ，为系统分析区域 $E T_{0}$ 的变化规律，本文研究了 $1960-2017$ 年生长季与非生长季 $E T_{0}$ 的变化特征。结果表明, $1960-2017$ 年间生长季平均 $E T_{0}$ 为 $933.9 \mathrm{~mm}$ ，远高于非生长季的 $239.7 \mathrm{~mm}$ 。 $E T_{0}$ 在生长 季和非生长季均呈现增长趋势, 但是增长速率有所差异, 其中生长季 $E T_{0}$ 的年际增长率 为 $16.6 \mathrm{~mm} / 10 \mathrm{a}$ ，而非生长季 $E T_{0}$ 的年际增长率为 $5 \mathrm{~mm} / 10 \mathrm{a}$ ，二者均通过了 0.01 水平的 显著性检验。此外，两个季节的 $E T_{0}$ 极值的出现时间也呈现明显的差异，生长季 $E T_{0}$ 最高 值出现在 1997 年，为 $1030.7 \mathrm{~mm}$ ，最低值出现在 1964 年，为 $824.2 \mathrm{~mm}$ 。而非生长季 $E T_{0}$ 最大值出现在 1998 年，为 $293.6 \mathrm{~mm}$ ，这与生长季差异显著，非生长季 $E T_{0}$ 最小值在 1975 年被观测到 $(201.8 \mathrm{~mm})$ 。

区域 $E T_{0}$ 与多种气象因子的关联性分析结果显示（表 1$)$ ，在整个研究时段，区域气 温及相对湿度变化对区域年均 $E T_{0}$ 的变化影响较大，其中相对湿度与年均 $E T_{0}$ 的变化呈显 著负相关，相关系数为 -0.662 ; 平均气温对区域年 $E T_{0}$ 的变化影响最明显，呈显著正相关 关系。生长季与非生长季的 $E T_{0}$ 变化同样与区域气温变化的关联性显著, 这说明研究区 
表 1 区域 $E T_{0}$ 变化与多种气象因子的相关分析

Table 1 The relationship between potential evapotranspiration and meteorological factors in the study area

\begin{tabular}{lcccccc}
\hline & 平均风速 & 平均气温 & 最高气温 & 最低气温 & 日照时数 & 相对湿度 \\
\hline 年 & $-0.478^{* *}$ & $0.889^{* *}$ & $0.809^{* *}$ & $0.506^{* *}$ & 0.215 & $-0.662^{* *}$ \\
生长季 & $-0.460^{* *}$ & $0.754^{* *}$ & $0.797^{* *}$ & $0.477^{* *}$ & 0.183 & $-0.569^{* *}$ \\
非生长季 & $-0.297^{*}$ & $0.537^{* *}$ & $0.659^{* *}$ & $0.316^{*}$ & 0.139 & $-0.344^{* *}$ \\
\hline
\end{tabular}

注: *”分别表示在 $0.05 、 0.01$ 水平上显著相关，下同。

$E T_{0}$ 的变化主要受控于区域气温的变化，未来气温的变化有可能引起区域 $E T_{0}$ 的改变。

\section{2 塬面保护区 $E T_{0}$ 的空间变化特征}

图 3 显示, 研究区东部的多年平均 $E T_{0}$ 值大于西部, 其中西部甘肃塬区 $E T_{0}$ 值远低 于东部山西塬区。多年 $E T_{0}$ 均值由东部山西塬区的 $1568.5 \mathrm{~mm}$ 减少至西部甘肃塬区的 $934.5 \mathrm{~mm}$ 。此外, 研究区的生长季和非生长季的 $E T_{0}$ 空间分布特征也表现为东部高西部 低的变化趋势, 其中生长季 $E T_{0}$ 的空间差异大于非生长季 $E T_{0}$ 的空间差异。在生长季，山 西塬区的 $E T_{0}$ 最大值出现在大宁站, 为 $1266.4 \mathrm{~mm}, E T_{0}$ 最小值出现在甘肃塬区的西峰 站, 为 $739.2 \mathrm{~mm}$ 。在非生长季, $E T_{0}$ 最大、最小值分别为 $316.8 \mathrm{~mm}$ 和 $195.3 \mathrm{~mm}$, 分别出 现在山西塬区的乡宁站和甘肃塬区的西峰站。

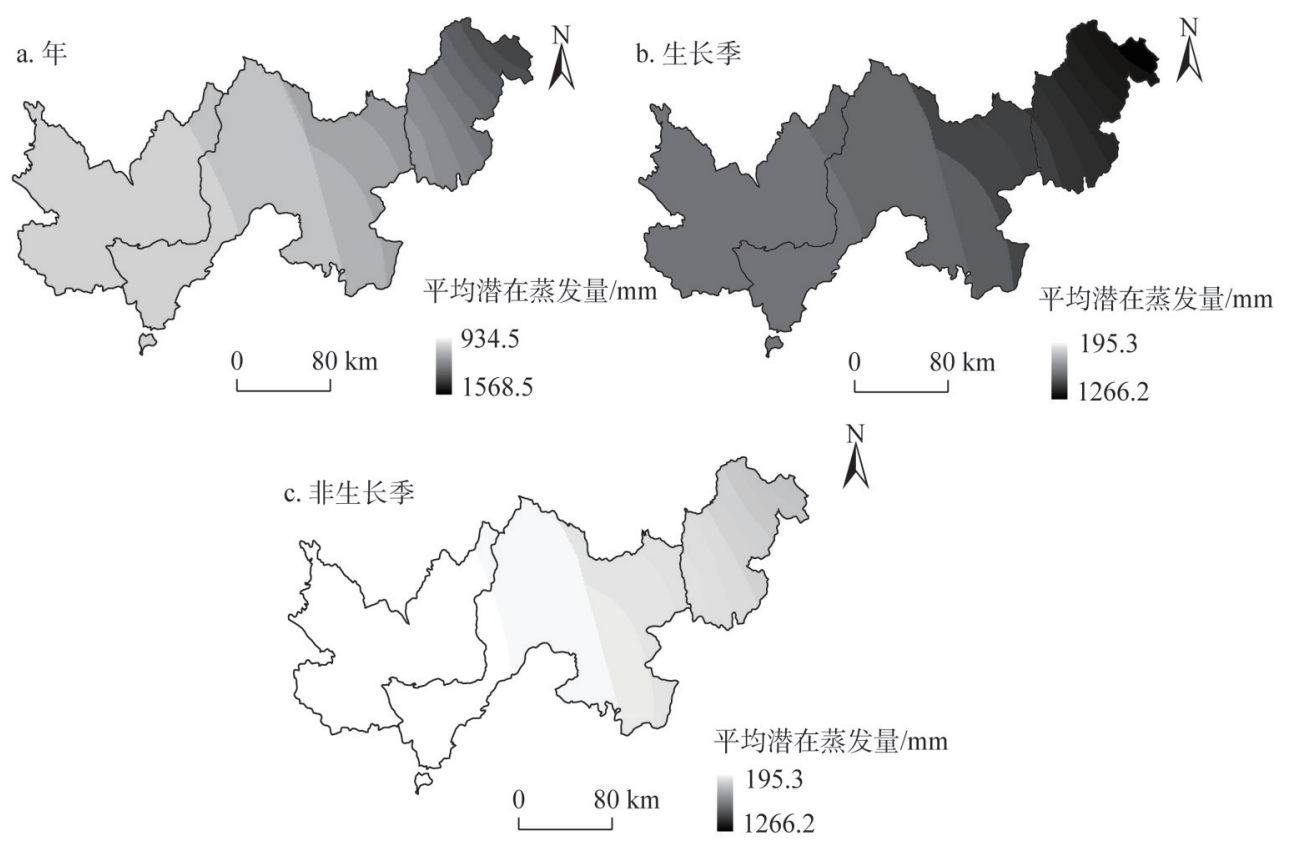

图 3 黄土塬面保护区 $E T_{0}$ 的空间分布特征

Fig. 3 Spatial distribution of potential evapotranspiration in the tableland protected region of the Loess Plateau during 1960-2017

对比分析三个不同的塬区发现（表2），影响其各自 $E T_{0}$ 时空分布规律的气象因子不 尽相同, 其中最高气温变化对甘肃塬区与山西塬区的 $E T_{0}$ 变化影响较为显著, 相关系数达 到了 0.889 和 0.915 ; 而在陕西塬区, 区域 $E T_{0}$ 的变化主要受控于区域相对湿度的变化。 


\section{表 2 三塬区的 $E T_{0}$ 变化与气象因子的相关分析}

Table 2 The relationship between potential evapotranspiration and meteorological factors in the three tableland regions

\begin{tabular}{cccccccc}
\hline & 时段/年 & 风速 & 平均气温 & 最高气温 & 最低气温 & 日照时数 & 相对湿度 \\
\hline 整体 & $1960-2017$ & $0.478^{* *}$ & $0.809^{* *}$ & $0.889^{* *}$ & $0.506^{* *}$ & 0.215 & $0.662^{* *}$ \\
甘肃塬区 & $1960-2017$ & 0.024 & $0.781^{* *}$ & $0.889^{* *}$ & $0.572^{* *}$ & $0.613^{* *}$ & $0.886^{* *}$ \\
山西塬区 & $1960-2017$ & $0.562^{* *}$ & $0.804^{* *}$ & $0.915^{* *}$ & 0.113 & 0.253 & $0.300^{*}$ \\
陕西塬区 & $1960-2017$ & $0.263^{*}$ & $0.652^{* *}$ & $0.770^{* *}$ & $0.436^{* *}$ & $0.575^{* *}$ & $0.827^{* *}$ \\
\hline
\end{tabular}

\section{3 塬面保护区 $E T_{0}$ 的趋势分析及周期分析}

\subsection{1 $E T_{0}$ 的趋势分析}

图 4 为研究区 $E T_{0}$ 的 Mann-Kendall 统计量 $Z$ 值空间分布图，如图所示，研究区年均 $E T_{0}$ 均呈现出增长趋势, 且地域差异明显。山西塬区除东北部呈现微弱上升趋势外，其余 地区均为显著增加趋势，通过了 0.01 显著性检验; 在陕西塬区，除东南部年均 $E T_{0}$ 增长趋 势不明显外，其余区域的年均 $E T_{0}$ 均呈显著增长；在甘肃塬区，年均 $E T_{0}$ 增长趋势整体 上较为一致。三个区域中，山西塬区的乡宁站年均 $E T_{0}$ 增长趋势最为显著，增长速率为 $6.31 \mathrm{~mm} / \mathrm{a}$; 而陕西塬区的合阳站的年均 $E T_{0}$ 增速最小，速率为 $1.99 \mathrm{~mm} / \mathrm{a}$ 。
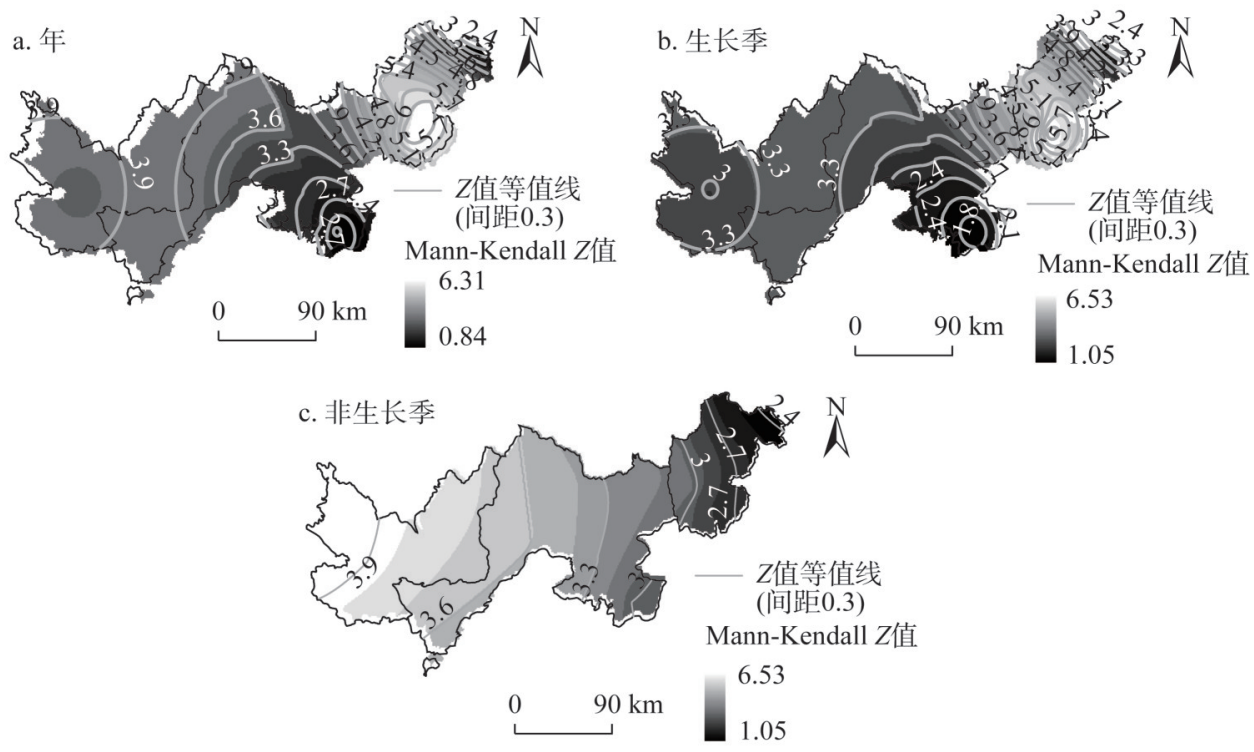

图 4 黄土塬面保护区 $E T_{0}$ 的 Mann-Kendall $Z$ 值空间分布特征

Fig. 4 Spatial distribution of Mann-Kendall's $Z$ value for potential evapotranspiration in the tableland protected region of the Loess Plateau during 1960-2017

研究区内生长季和非生长季的 $E T_{0}$ 变化趋势与年 $E T_{0}$ 变化趋势较为相似，均呈现增长 趋势，但是空间差异也较显著（图 4)。生长季 $E T_{0}$ 增长趋势以山西塬区最为显著, 甘肃 塬区其次，陕西塬区最小。增长速率最快的是山西塬区的乡宁站，达到 $6.53 \mathrm{~mm} / \mathrm{a}$ ，增长 速率最小的是陕西塬区的合阳站, 为 $1.54 \mathrm{~mm} / \mathrm{a}$ 。非生长季 $E T_{0}$ 增长趋势以甘肃塬区最为 显著, 其次为陕西塬区, 山西塬区不明显。其中甘肃塬区的崆峒站增速最大, 通过了 0.01 显著性检验（ $|Z|>2.58)$; 山西塬区的乡宁站最小，为 $1.99 \mathrm{~mm} / \mathrm{a}$ 。 


\subsection{2 $E T_{0}$ 的周期变化}

图 5 为 1960-2017 年间研究区 $E T_{0}$ 的 Morlet 小波实部时频分布等高线图及小波方差 图。由图可知，研究区年均 $E T_{0}$ 在 30 年左右的震荡最为明显，其次是 10 年和 50 年; 年均 $E T_{0}$ 具有三个明显的小波方差峰值，分别对应着周期为 10 年、 30 年和 50 年，表明研究区 年均 $E T_{0}$ 变化存在着 10 年、 30 年和 50 年的震荡周期，其中 30 年为研究区多年 $E T_{0}$ 变化的 主周期（图 $5 \mathrm{a} ）$ 。而研究区生长季和非生长季 $E T_{0}$ 的周期变化与年均 $E T_{0}$ 变化周期大体一 致，也表现出 30 年的主周期变化规律，但在两个季节的 $E T_{0}$ 的 50 年左右周期中均有小幅 度的提前。

\section{3 结论与讨论}

\section{1 结论}

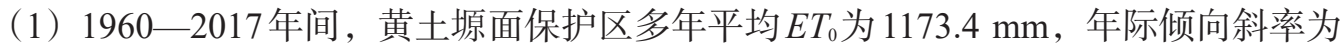
$21.1 \mathrm{~mm} / 10 \mathrm{a}$ ，总体呈现增长趋势。其中生长季平均 $E T_{0}(933.9 \mathrm{~mm}$ ) 值远高于非生长季 $(239.7 \mathrm{~mm})$, 生长季 $E T_{0}$ 增长速率大于非生长季。
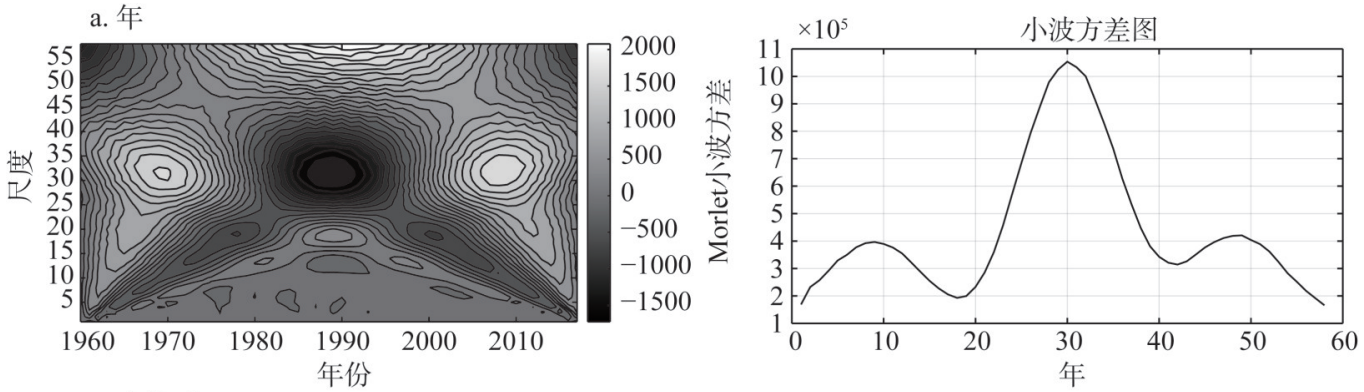

b. 生长季
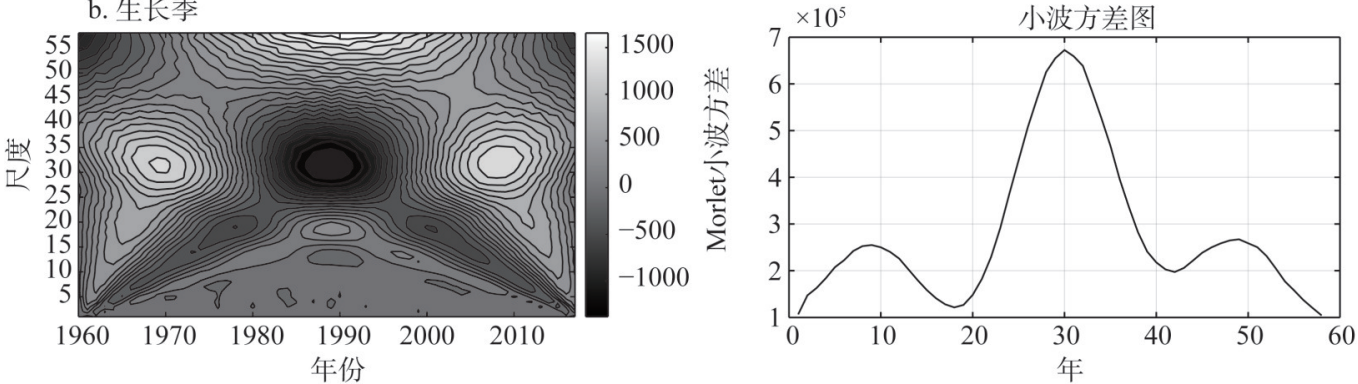

c. 非生长季
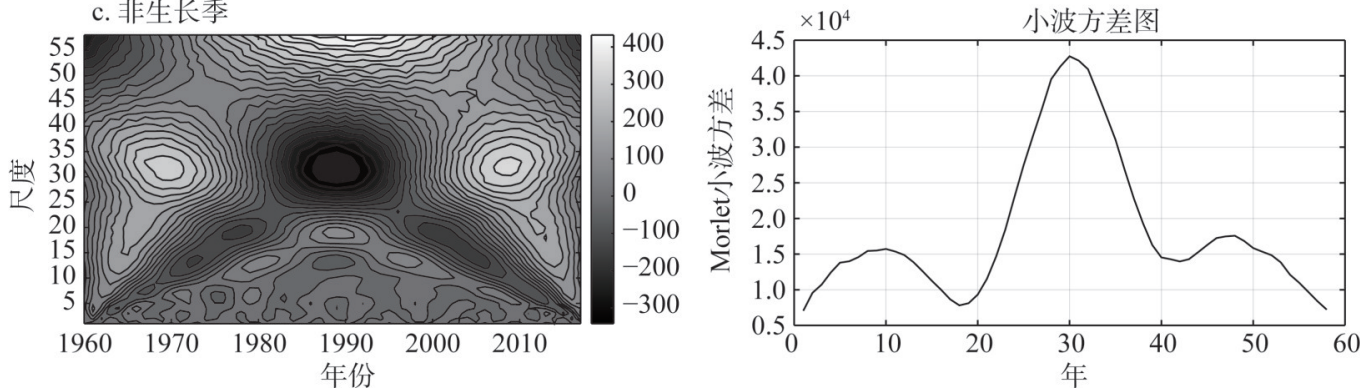

图 5 研究区 $E T_{0}$ 动态变化的小波分析

Fig. 5 The wavelet analysis of the variation of potential evapotranspiration in the study area 
(2) 研究区多年平均 $E T_{0}$ 值在空间上表现为东部高西部低，西部甘肃塬区 $E T_{0}$ 远低于 东部山西塬区; 研究区三个塬区的年均 $E T_{0}$ 呈现出增长趋势, 但是地域差异明显。生长季 和非生长季的 $E T_{0}$ 与年 $E T_{0}$ 变化一致, 呈增加趋势, 其中生长季 $E T_{0}$ 增长趋势以山西塬区 最为显著, 非生长季 $E T_{0}$ 增长趋势以甘肃塬区最为显著。研究区 $E T_{0}$ 变化存在着 10 年、30 年和 50 年的震荡周期，其中 30 年左右周期为主周期。

(3) 气温是影响研究区 $E T_{0}$ 变化的主导因素，其中对于整个研究区的 $E T_{0}$ 变化，贡献 率最大的是最低气温; 而在甘肃塬区和陕西塬区, 平均气温对区域 $E T_{0}$ 变化贡献率最大; 最高气温的变化对山西塬区 $E T_{0}$ 的变化贡献最明显。除此之外，相对湿度对陕西塬区 $E T_{0}$ 变化具有较高的贡献率。遥相关分析结果显示, 太平洋/北美震荡指数（PNA）与北大西 洋年代尺度振荡（AMO）波动会影响区域 $E T_{0}$ 变化，北大西洋年代尺度振荡（AMO）的 相关性更强, 西太平洋海温指数（WPI）的变化对区域非生长季 $E T_{0}$ 变化产生影响。

\section{2 讨论}

\subsection{1 区域 $E T_{0}$ 影响因素分析}

\section{(1) 气象因子对年 $E T_{0}$ 的贡献}

表 3 为黄土塬面保护区各气象因子对 $E T_{0}$ 变化的贡献率。在 1960-2017年间，气温对于 整个研究区、甘肃、山西和陕西塬区的区域 $E T_{0}$ 变化的贡献率均最大，但不同区域，气温 的贡献率存在差异。最低气温对整体研究区的 $E T_{0}$ 变化的贡献率最高。而在甘肃塬区和陕 西塬区, 平均气温变化对其区域 $E T_{0}$ 变化贡献率最大。在山西塬区, 最高气温对 $E T_{0}$ 变化 贡献率最大。除此之外，相对湿度对陕西塬区的 $E T_{0}$ 变化具有较高的贡献率。

\section{表 3 气象因子对年 $E T_{0}$ 变化的贡献率}

Table 3 The contribution of meteorological factors to the regional potential evapotranspiration

\begin{tabular}{cccccccc}
\hline & 时段/年 & 风速 & 平均气温 & 最高气温 & 最低气温 & 日照时数 & 相对湿度 \\
\hline 整体 & $1960-2017$ & 0.02 & 0.23 & 0.14 & 0.31 & 0.05 & 0.05 \\
甘肃塬区 & $1960-2017$ & 0.02 & 0.48 & 0.11 & 0.29 & 0.01 & 0.09 \\
山西塬区 & $1960-2017$ & 0.13 & 0.19 & 0.38 & 0.10 & 0.02 & 0.18 \\
陕西塬区 & $1960-2017$ & 0.12 & 0.28 & 0.07 & 0.20 & 0.06 & 0.27 \\
\hline
\end{tabular}

(2) 大气环流指数与区域 $E T_{0}$ 的遥相关分析

遥相关是指远距离的两个地点大气环流变化存在相关性 ${ }^{[27]}$ 。1950年以来发现的北大 西洋涛动 $(\mathrm{NAO})$ 、南方涛动 $(\mathrm{SO})$ 、太平洋/北美指数（PNA）均为典型的遥相关现 象。此后, 众多学者开展了有关遥相关的研究, 并且在理论和数据等方面取得了许多重 要的成果。如龚道溢等 ${ }^{[28]}$ 证明 $\mathrm{NAO}$ 、北太平洋涛动（NPO）及 $\mathrm{SO}$ 均影响北半球气温变 化; 李沛等 ${ }^{[29]}$ 发现北极涛动（AO）会影响流域降水结构的变化; 丁一汇等 ${ }^{[13]}$ 发现北大西 洋年代尺度振荡（AMO）对东亚季风产生影响; 李春辉等 ${ }^{[14]}$ 指出西太平洋海温指数 （WPI）与中国冬季气候异常相关。在黄土高原的研究表明，区域气候水文过程亦存在遥 相关现象。如蓝永超等 ${ }^{[30]}$ 发现厄尔尼诺/南方涛动（ENSO）现象与黄河上游的径流丰枯 关系密切; 赵强等 ${ }^{[12]}$ 发现 PNA 对陕西地区的降水产生影响。基于以上学者的研究, 本文 选取可能对区域 $E T_{0}$ 变化存在遥相关关系的 NAO、AO、ENSO、PNA、AMO 与 WPI等 6 个大尺度环流因子，分析其与研究区 $E T_{0}$ 的关联性。根据主要大尺度环流因子与 $E T_{0}$ 的遥 相关分析结果显示 (表 4$)$, 研究区年均 $E T_{0}$ 变化与太平洋/北美指数（PNA）、北大西洋年 
表 4 大尺度环流因子与 $E T_{0}$ 的关联性分析

Table 4 The relationship between potential evapotranspiration and the circulation factors

\begin{tabular}{lcccccc}
\hline 不同类型 $E T_{0}$ & $\mathrm{NAO}$ & $\mathrm{AO}$ & $\mathrm{ENSO}$ & $\mathrm{PNA}$ & AMO & WPI \\
\hline 年 & -0.055 & -0.038 & 0.002 & $0.278^{*}$ & $0.597^{* *}$ & -0.081 \\
生长季 & $-0.326^{*}$ & -0.136 & 0.094 & 0.046 & $0.577^{* *}$ & -0.308 \\
非生长季 & 0.109 & -0.167 & 0.019 & 0.18 & $0.402^{* *}$ & $0.433^{* *}$ \\
甘肃塬区 & -0.122 & -0.128 & 0.008 & $0.293^{*}$ & $0.487^{* *}$ & -0.004 \\
山西塬区 & -0.007 & 0.010 & -0.01 & $0.321^{*}$ & $0.673^{* *}$ & -0.114 \\
陕西塬区 & -0.088 & -0.064 & 0.016 & 0.167 & $0.440^{* *}$ & -0.052 \\
\hline
\end{tabular}

代尺度振荡（AMO）存在遥相关关系, 这表明 PNA 与 AMO 对区域蒸散发的变化有一定 影响。当PNA 为正位相时, 夏季西太平洋副高增强并西向位移，我国夏季降水增多，进 而导致研究区潜在蒸散发的变化; 而 $\mathrm{AMO}$ 处于正位相时, 北大西洋温度升高导致热带中 太平洋地区降水减少，从而带来西太平洋的东风和北半球其他区域的西风发生改变，使 得北半球夏季风环流及降水增强。并且其为正位相也对东亚冬季风产生影响, 我国大部 分地区冬季温度升高, 进而对研究区年均 $E T_{0}$ 变化产生影响。

研究区两个季节的 $E T_{0}$ 变化都与 $\mathrm{AMO}$ 存在较为显著的遥相关关系, 而非生长季 $E T_{0}$ 变化还与 WPI 的变化存在一定关联性。WPI的正负异常往往会改变副热带高压西向影响 的强度, 当WPI 为正时, 北太平洋西部区域海温值比同一时期的多年平均值要高 ${ }^{[1]}$, 西 太平洋副高向西强度减弱, 对应的研究区的非生长季气温偏低, 进而导致该时期区域 $E T_{0}$ 值偏低。在三个塬区中, 山西塬区的年均 $E T_{0}$ 变化与 $\mathrm{AMO}$ 波动间的关联性最高, 甘肃塬 区次之，陕西塬区较低，但均通过了 0.01 水平的显著性检验。

\subsection{2 $E T_{0}$ 结果验证}

对比已有的研究发现, 在过去 58 年来, 陕西塬区年均 $E T_{0}$ 变化趋势与陕北黄土高原 区的研究结果跤为相似, 区域年均 $E T_{0}$ 均呈增长趋势, 但是增长率较低。而在甘肃塬 区，区域 $E T_{0}$ 变化趋势与刘普幸 ${ }^{[2]}$ 等学者在甘肃等地区的研究结果相似。这些都进一步验 证了本文计算的 $E T_{0}$ 结果的准确性。

此外，本文选取乡宁、蒲县、吉县和汾西 4 个站点的蒸发血蒸发量均值与区域 $E T_{0}$ 估 算值进行了比较。数据误差检验结果 显示 (表 5), 各站点误差均保持在 $(-18,16)$ 之间，误差相对较小，这表 明本文计算的 $E T_{0}$ 值可信度较高。此 外研究时段内 $E T_{0}$ 的估算值与蒸发血. 蒸发量变化趋势相似, 表明本文 $E T_{0}$ 估算值可以反映出黄土塬面保护区 $E T_{0}$ 的时空变化特征。

表 $5 E T_{0}$ 的估算值和蒸发血蒸发量的比较

Table 5 Comparison of estimated and observed values of potential evapotranspiration

\begin{tabular}{lcccc}
\hline & 乡宁 & 蒲县 & 汾西 & 吉县 \\
\hline$E T_{0}$ 估算值 $/ \mathrm{mm}$ & 56.3 & 52.4 & 52.8 & 40.7 \\
蒸发血蒸发量 $/ \mathrm{mm}$ & 47.9 & 47.0 & 47.1 & 48.3 \\
误差 $/ \%$ & -17.6 & -11.4 & -12.1 & 15.6 \\
\hline
\end{tabular}

\section{参考文献(References):}

[1] CHONG J, MU X, FEI W, et al. Analysis of extreme temperature events in the Qinling Mountains and surrounding area during 1960-2012. Quaternary International, 2016, 392(4): 155-167.

[2] 黄会平, 曹明明, 宋进喜, 等. 1957-2012 年中国参考作物蒸散量时空变化及其影响因子分析. 自然资源学报, 2015, 
30(2): 315-326. [HUANG H P, CAO M M, SONG J X, et al. Temporal and spatial changes of potential evapotranspiration and its influencing factors in China from 1957 to 2012. Journal of Natural Resources, 2015, 30(2): 315-326.]

[3] 董显, 海米提・依米提. 1961-2013 年新疆潜在蒸散量变化特征及趋势. 农业工程学报, 2015, 31(1): 153-161. [DONG Y, HAIMITI Y. Spatio-temporal variability and trend of potential evapotranspiration in Xinjiang from 1961 to 2013. Transactions of the CSAE, 2015, 31(1): 153-161.]

[4] 叶红, 张廷斌, 易桂花, 等. 2000-2014年黄河源区 ET 时空特征及其与气候因子关系. 地理学报, 2018, 73(11): 21172134. [YE H, ZHANG T B, YI G H, et al. Spatio-temporal characteristics of evapotranspiration and its relationship with climate factors in the Source Region of the Yellow River from 2000 to 2014. Acta Geographica Sinica, 2018, 73(11): 2117-2134.]

[5] MOHAMMAD V. Analysis of potential evapotranspiration using limited weather data. Applied Water Science, 2017, 7 (14): 187-197.

[6] DANLU G, SETH W, MAIER H. Sensitivity of potential evapotranspiration to changes in climate variables for different Australian Climatic Zones. Hydrology and Earth System Sciences, 2017, 21(4): 2107-2126.

[7] 韩盟伟, 赵广举, 穆兴民, 等. 黄土高原 1959-2015 年潜在蒸发量的时空变化. 干旱区地理: 汉文版, 2017, 40(5): 997-1004. [HAN M W, ZHAO G J, MU X M, et al. Spatial and temporal variations of potential evapotranspiration on the Loess Plateau during 1959-2015. Arid Land Geography, 2017, 40(5): 997-1004.]

[8] LI C, WU P T, LI X L, et al. Spatial and temporal evolution of climatic factors and its impacts on potential evapotranspiration in Loess Plateau of Northern Shaanxi, China. Science of the Total Environment, 2017, 589(2): 165-172.

[9] NING T, LI Z, LIU W, et al. Evolution of potential evapotranspiration in the Northern Loess Plateau of China: Recent trends and climatic drivers. International Journal of Climatology, 2016, 36(12): 135-144.

[10] 梅星, 沈冰, 莫淑红, 等. 黄土高原丘陵沟壑区蒸发量的模拟及其变化趋势和影响因素分析. 见: 西安理工大学西北 水资源与环境生态教育部重点实验室. 第八届中国水论坛论文集. 西安: 西安理工大学, 2010: 534-538. [MEI X, SHEN B, MO S H, et al. Simulation and variation trend of evapotranspiration in hilly and gully region of Loess Plateau and influence factor analysis. In: Key Laboratory of Northwest Water Resource and Environment Ecology of Ministry of Education, Xian University of Technology. The Proceedings of $8^{\text {th }}$ China water BBS abstract collection. Xi'an: Xian University of Technology, 2010: 534-538.]

[11] 孙从建, 郑振婧, 李伟, 等. 1964-2017年山西省潜在蒸发量时空变化及其影响因素分析. 水土保持研究, 2019, 26 (5): 229-235. [SUN C J, ZHENG Z J, LI W, et al. Spatial and temporal variation characteristics of potential evapotranspiration and its impact factors of Shanxi province during 1 964-2017. Research of Soil and Water Conservation, 2019, 26(5): 229-235.]

[12] 赵强, 严华生, 张谨文. 影响陕西夏季早涝的北半球前期大气环流特征. 干旱气象, 2012, 30(4): 546-554. [ZHAO Q, YAN H S, ZHANG J W. Preceding atmospheric circulation characteristics over northern hemisphere innuencing on droughts and floods in summer of Shaanxi. Journal of Arid Meteorology, 2012, 30(4): 546-554.]

[13] 丁一汇, 柳艳菊, 梁苏洁, 等. 东亚冬季风的年代际变化及其与全球气候变化的可能联系. 气象学报, 2014, 72(5): 835-852. [DING Y H, LIU Y J, LIANG S J, et al. Interdecadal variability of the East Asian w inter monsoon and its possible links to global climate change. Acta Meteorologica Sinica, 2014, 72(5): 835-852.]

[14] 李春晖,管兆勇,何金海, 等. 西太平洋海温和南方涛动与中国冬季气候异常关系年代际变化的对比分析. 应用气象 学报, 2005, 16(1): 105-113. [LI C H, GUAN Z Y, HE J H, et al. Contrast analysis of the interdecadal variation of the relation among the Western Pacific/the Southern Oscillation and the winter climate anomalies in China. Journal of Applied Meteorological Science Original Article, 2005, 16(1): 105-113.]

[15] 唐见, 曹慧群, 陈进. 长江源区水文气象要素变化及其与大尺度环流因子关系研究. 自然资源学报, 2018, 33(5): 840-852. [TANG J, CAO H Q, CHEN J. Changes of hydro-meteorological factors and the relationships with large-scale circulation factors in the source region of the Yangtze River. Journal of Natural Resources, 2018, 33(5): 840-852.]

[16] 毕华兴, 刘立斌, 刘斌. 黄土高塬沟壑区水土流失综合治理范式. 中国水土保持科学, 2010, 8(4): 27-33. [BI H X, LIU L B, LIU B. Integrated management paradigm of soil and water loss in gully region of Loess Plateau. Science of Soil and Water Conservation, 2010, 8(4): 27-33.]

[17] 孟宪玲, 孙从建, 尹慧敏. 谈谈黄土高原塬面治理问题. 山西水土保持科技, 2017, 12(4): 35-36. [MENG X L, SUN C 
J, YIN H M. Talk about the Loess Plateau Table-land governance issues. Soil and Water Conservation Science and Technology in Shanxi, 2017, 12(4): 35-36.]

[18] 陈绍宇, 许建民, 王文龙, 等. 黄土高塬沟壑区董志塬沟头溯源侵蚀特征及其防治途径. 水土保持通报, 2009, 29(4): 37-41. [CEHN S Y, XU J M, WANG W L, et al. Characteristics of source erosion of Dongzhi Tableland Gully Head and its prevention and control methods. Water and Soil Conservation Bulletin, 2009, 29(4): 37-41.]

[19] 胡振华, 冯慧敏, 王电龙, 等. 晋西黄土残塬沟壑区塬坡坡面土壤水分特征分析. 山西农业大学学报: 自然科学版, 2009, 29(3): 257-260. [HU Z H, FENG H M, WANG D L, et al. Analysis of soil moisture characteristics on the slopes of the Loess Plateau in the gully region of Western Shanxi province. Journal of Shanxi Agricultural University: Nature Science, 2009, 29(3): 257-260.]

[20] 唐登银, 程维新, 洪嘉牫. 我国蒸发研究的概况与展望. 地理研究, 1984, 3(3): 84-97. [TANG D Y, CHENG W X, HONG J L. Overview and prospect of evapotranspiration research in China. Geographical Research, 1984, 3(3): 84-97.]

[21] 李晗, 赵娜, 岳天祥, 等. 基于 HASM 方法的黑河流域 ET0 的模拟. 地球信息科学学报, 2017, 19(11): 66-74. [LI H, ZHAO N, YUE T X, et al. Simulation of potential evapotranspiration in Heihe River Basin based on HASM method. Journal of Geo-Information Science, 2017, 19(11): 66-74.]

[22] 张东艳, 吴运卿, 李妮. 基于 Mann-Kendall 检验的尼洋河流域水文变量演变趋势分析. 中国农村水利水电, 2017, (12): 86-89. [ZHANG D Y, WU Y Q, LI N. Analysis on the evolution trend of hydrological variables in Niyang River Basin based on Mann-Kendall Test. China Rural Water Conservancy and Hydropower, 2017, (12): 86-89.]

[23] 孙从建, 李伟, 李新功, 等. 青藏高原西北部近地表气温直减率时空分布特征. 自然资源学报, 2018, 33(7): 12701282. [SUN C J, LI W, LI X G, et al. Spatio-temporal variation of near-surface temperature lapse rates over the Northwestern Tibetan Plateau. Journal of Natural Resources, 2018, 33(7): 1270-1282.]

[24] 徐克兵. 雅鲁藏布江干流河川径流变化的小波分析. 东北水利水电, 2014, 32(1): 38-40. [XU K B. Wavelet analysis of runoff change in main stream of Yarlung Zangbu River. Northeast Water Conservancy and Hydropower, 2014, 32(1): 38-40.]

[25] 郭晓英, 陈兴伟, 陈莹, 等. 气候变化与人类活动对闽江流域径流变化的影响. 中国水土保持科学, 2016, 14(2): 8894. [GUO X Y, CEHN X W, CHEN Y, et al. Impacts of climate variability and human activities on runoff of Minjiang River Basin. Science of Soil and Water Conservation, 2016, 14(2): 88-94.]

[26] 赵春雨, 王颖, 张玉书, 等. 近 50年辽宁省作物生长季气候条件变化及对农业生产的影响. 灾害学, 2009, 24(4): 102106. [ZHAO C Y, WANG Y, ZHENG Y S, et al. Climate conditions of crop growth season and its effect on agricultural production in the recent 50 years in Liaoning province. Journal of Catastrophology, 2009, 24(4): 102-106.]

[27] 陶祖钰. 大气的遥相关现象. 广西气象, 1988, 2(9): 3-7. [TAO Z Y. Remote correlation of the atmosphere. Journal of Guangxi Meteorology, 1998, 2(9): 3-7.]

[28] 龚道溢, 王绍武. 大气环流因子对北半球气温变化影响的研究. 地理研究, 1999, 18(1): 31-38. [GONG D Y, WANG S W. Influence of atmospheric oscillations on northern hemispheric temperature. Geographical Research, 1999, 18(1): 31-38.]

[29] 李沛, 黄生志, 黄强, 等. 大通河流域降水结构的演变特征及其驱动力探究. 自然资源学报, 2018, 33(9): 1588-1598. [LI P, HUANG S Z, HUANG Q, et al. Study on the evolution characteristics and driving forces of rainfall structure in Datong River Basin. Journal of Natural Resources, 2018, 33(9): 1588-1598.]

[30] 蓝永超, 马全杰, 康尔泗, 等. ENSO循环与黄河上游径流的丰枯. 中国沙漠, 2002, 22(3): 262-266. [LAN Y C, MA Q J, KANG E S, et al. Relationship between ENSO cycle and abundant or low runoff in the Upper Yellow River. Journal of Desert Research, 2002, 22(3): 262-266.]

[31] 罗亚松, 黄凯, 于翚. 流域降水与大尺度气候因子关系识别. 海河水利, 2017, 4(8): 38-41. [LUO Y S, HUANG K, YU H. Identification of relationship between watershed precipitation and large-scale climate factors. Haihe Water Resources, 2017, 4(8): 38-41.]

[32] 刘普幸, 卓玛兰草. 甘肃省 1960-2008 年潜在蒸散量时空变化及其影响因子. 自然资源学报, 2012, 27(9): 15611571. [LIU P X, ZHUOMA L C. Temporal and spatial change of the potential evaporation and its impact factors in Gansu province. Journal of Natural Resources, 2012, 27(9): 1561-1571.] 


\title{
Spatio-temporal distribution of the potential evapotranspiration and its controlling factors in the tableland protected region of the Loess Plateau
}

\author{
SUN Cong-jian ${ }^{1,2}$, ZHENG Zhen-jing ${ }^{1}$, LI Xin-gong ${ }^{1}$, SUN Jiu-lin ${ }^{1,3}$ \\ (1. School of Geographical Sciences, Shanxi Normal University, Linfen 041000, Shanxi, China; 2. State Key \\ Laboratory of Desert and Oasis Ecology, Xinjiang Institute of Ecology and Geography, CAS, Urumqi 830011, \\ China; 3. Institute of Geographic Sciences and Natural Resources Research, CAS, Beijing 100101, China)
}

\begin{abstract}
The tableland protected region, as a major region for agriculture and habitation, plays an important role in the Loess Plateau. The information of the regional potential evapotranspiration $\left(E T_{0}\right)$ and its distribution on the Loess Plateau are beneficial to the reorganization in regional water cycle, control on the soil erosion and sustainable development of agriculture. Based on the meteorological data of the tableland protected regions of the Loess Plateau during 1960-2017, the spatial and temporal distribution of the $E T_{0}$ and its controlling factors were analyzed by using the Penman-Monteith model, wavelet analysis, Mann-Kendall test and ArcGIS. The results are shown as follows: (1) The average $E T_{0}$ of the study area is $1173.4 \mathrm{~mm}$, which shows a significant increasing trend with a rate of $21.1 \mathrm{~mm} / 10 \mathrm{a}$. The average $E T_{0}$ in growing season is much higher than that in the non-growing season. (2) The spatial distribution of the multi-year annual average $E T_{0}$ in the study area decreased from the east to the west, and the multi-year average $E T_{0}$ in the western Gansu tableland is far lower than that in the eastern Shanxi tableland. (3) Over the past 58 years, the average $E T_{0}$ of the whole study area, growth season and non-growth season showed a significant increasing trend, but the spatial variations are remarkable. There were 10-year, 30-year and 50-year oscillation periods in the variation of average $E T_{0}$ in the study area, of which the 30 -year oscillation is the main oscillation period during the past 58 years. (4) Air temperature is the most important meteorological factor controlling $E T_{0}$ change in the region, but the influence of air temperature on $E T_{0}$ change shows an obvious spatial difference. The lowest temperature has the most significant effect on the $E T_{0}$ change of the whole study area. The changes of $E T_{0}$ in the Gansu tableland and Shaanxi tableland are mainly affected by the change of average temperature. The change of maximum temperature in Shanxi tableland has significant influence on regional $E T_{0}$. (5) The Pacific/North America index (PNA) and the Atlantic Multi-decadal Oscillation (AMO) are associated with the regional $E T_{0}$ change, while the $E T_{0}$ change of the non-growing season is related to the change of the WPI.
\end{abstract}

Keywords: potential evapotranspiration; Penman- Monteith model; spatio- temporal distribution; influencing factor; the tableland protected region of the Loess Plateau 